\title{
Farmers' Perceptions of Commercial Insect-Based Feed for Sustainable Livestock Production in Kenya
}

\author{
Afrika Onguko Okello ${ }^{1,2, *}$, Jonathan Makau Nzuma ${ }^{1}$, David Jakinda Otieno ${ }^{1}$, Michael Kidoido ${ }^{2, *}$ \\ and Chrysantus Mbi Tanga ${ }^{2}$ (D) \\ 1 Department of Agricultural Economics, University of Nairobi, Kangemi P.O. Box 29053-00625, Kenya; \\ jonathan_nzuma@yahoo.com (J.M.N.); jakinda1@yahoo.com (D.J.O.) \\ 2 International Centre of Insect Physiology and Ecology (ICIPE), Nairobi P.O. Box 30772-00100, Kenya; \\ ctanga@icipe.org \\ * Correspondence: aokello@icipe.org or afreaqokello@gmail.com (A.O.O.); mkidoido@icipe.org (M.K.)
}

check for updates

Citation: Okello, A.O.; Nzuma, J.M.; Otieno, D.J.; Kidoido, M.; Tanga, C.M Farmers' Perceptions of Commercial Insect-Based Feed for Sustainable Livestock Production in Kenya. Sustainability 2021, 13, 5359. https:// doi.org/10.3390/su13105359

Academic Editor: Philipp Aerni

Received: 11 April 2021

Accepted: 5 May 2021

Published: 11 May 2021

Publisher's Note: MDPI stays neutral with regard to jurisdictional claims in published maps and institutional affiliations.

Copyright: (c) 2021 by the authors. Licensee MDPI, Basel, Switzerland. This article is an open access article distributed under the terms and conditions of the Creative Commons Attribution (CC BY) license (https:/ / creativecommons.org/licenses/by/ $4.0 /)$.

\begin{abstract}
The utilization of insect-based feeds (IBF) as an alternative protein source is increasingly gaining momentum worldwide owing to recent concerns over the impact of food systems on the environment. However, its large-scale adoption will depend on farmers' acceptance of its key qualities. This study evaluates farmer's perceptions of commercial IBF products and assesses the factors that would influence its adoption. It employs principal component analysis (PCA) to develop perception indices that are subsequently used in multiple regression analysis of survey data collected from a sample of 310 farmers. Over $90 \%$ of the farmers were ready and willing to use IBF. The PCA identified feed performance, social acceptability of the use of insects in feed formulation, feed versatility and marketability of livestock products reared on IBF as the key attributes that would inform farmers' purchase decisions. Awareness of IBF attributes, group membership, off-farm income, wealth status and education significantly influenced farmers' perceptions of IBF. Interventions such as experimental demonstrations that increase farmers' technical knowledge on the productivity of livestock fed on IBF are crucial to reducing farmers' uncertainties towards acceptability of IBF. Public partnerships with resource-endowed farmers and farmer groups are recommended to improve knowledge sharing on IBF.
\end{abstract}

Keywords: environment; insect-based feed; multiple regressions; perceptions; principal component analysis

\section{Introduction}

Intensification of agricultural production that improves the competitiveness and profitability of livestock enterprises is one option that can increase food production and reduce poverty in Africa [1]. Poultry, fish and pig production are the fastest growing agribusinesses in sub-Saharan Africa (SSA) providing income and employment opportunities for the population. In Kenya, the livestock sub-sector contributes about $12 \%$ to gross domestic product (GDP) and 47\% of agricultural GDP [2]. In addition, $66 \%$ of Kenyan households keep at least one type of livestock with $98 \%$ of the rural households keeping poultry [3]. Poultry keeping is one of the most popular livestock enterprises in Kenya due to its low capital and space requirements. It contributes about 55\% to the livestock sector GDP and $30 \%$ of the agricultural GDP, or $7.8 \%$ of Kenya's GDP [4]. The sub-sector employs about two million people [4] directly in production and marketing and indirectly through linkages with suppliers of inputs such as day-old chicks, feed and veterinary services.

Kenya's poultry sub-sector can increase household incomes and contribute to food and nutrition security through the provision of eggs, meat and manure. However, its potential is hampered by the high cost of production with the cost of feed alone amounting to over $70 \%$ of the production costs [5]. Owing to the high cost of commercial feed, chicken farmers in Kenya have resorted to formulating their own feed, and/or the inappropriate 
administration of growth hormones [6]. The own formulated feed often does not meet the required nutritional requirements for the birds [7]. Furthermore, the country's reliance on cheap imports of feed and protein ingredients from neighboring countries makes local feed production unsustainable [3]. The situation is exacerbated by non-tariff barriers (NTBs) to trade that hamper the consistent supply of feed ingredients and unanticipated recent crises brought forth by climate change and global pandemics such as that of coronavirus disease 2019 (Covid-19).

Insects have been proven to be potential alternatives to animal and plant protein sources worldwide [8]. Although insects occupy $80 \%$ of the global biodiversity and have been part of traditional delicacies for over two billion people, they are among the most underutilized feed resources $[9,10]$. The sustainable utilization of insects in livestock feed formulation has the potential to transform the current overreliance on fishmeal and soybean meal to a vibrant circular economy that offers employment opportunities especially for youths and women at the grassroots with effective feedbacks to the environment. The use of insect protein, particularly the black soldier fly (BSF), in livestock feed formulation is being explored globally [11-14].

Several milestones in this regard have been achieved $[5,12,15,16]$. In the European Union, whereas appropriate legislative steps are being initiated to integrate insect protein into feed formulation processes for poultry and pig production, the use of insects in fish feed has been approved $[8,17,18]$. In Kenya, reference [19] generated business models for insect-rearing for smallholder farmers in a way that would ensure profitability and environmental sustainability. Reference [20] demonstrated that the BSF is locally available in wild ecosystems and can be easily harvested for commercial feed production.

Understanding the context and needs of the target groups prior to the release of the innovations facilitates a favorable reception of the technology. Therefore, initiatives on awareness creation to boost farmers' perceptions have been promoted in recent literature [21-23]. According to [24], understanding farmers' perceptions provides an accurate reflection of their contextual situation, which could be an impediment to the uptake of innovations. Traditionally, insects are associated with disgust [25], dirt and are considered to be pests, hence the belief that they should be eliminated from the food supply chain [26,27]. Thus, understanding farmers' perceptions of insect-based feeds (IBF) is an important starting point in initiatives that seek to improve livestock welfare through conscious feeding practices and effective management of their health $[28,29]$.

Following [22], this study defines perception as the cognitive interpretation and understanding of the comparative characteristics of insect proteins in livestock feeds over conventional fishmeal and soybean protein. We build on the work of [30] who described the attitudes and knowledge of livestock farmers towards use of insects as a feed alternative in Kenya. This study examines the factors that can support behavioral change of livestock farmers with respect to improved and cost-effective insect-based feeds by synthesizing evidence collected from chicken farmers in Kiambu County, Kenya. The paper sought to answer two questions namely: "What do farmers think (farmer's general view) about IBF?" and "What are the factors that influence their thinking?"

Several interdependent factors motivate the undertaking of the study in Kiambu County. First, livestock production is the most prioritized value chain in the county [31]. Besides being connected to nearby markets by a good network of paved roads, an important aspect for farmers' access to markets in developing countries, the county enjoys close proximity to the city of Nairobi that has a high demand for livestock products [28,32]. Reference [33] noted that more than $50 \%$ of the population in Nairobi consume chicken products. Moreover, the use of affordable and quality feeds like IBF can be a viable option for improving livelihoods in the county where $23 \%$ of the households live below the poverty line [34].

A principal component analysis (PCA) was used to construct five perception indices that are used in multiple linear regressions to evaluate the factors influencing farmers' perceptions on IBF. We find chicken farmers in Kiambu County, Kenya, have favourable 
perceptions of commercial IBF and recommend that policy interventions should be geared towards increasing farmers' technical knowledge and ability to evaluate the performance of different animal breeds reared on IBF through technical training at group level to capitalize on peer learning. The remainder of the paper is organized as follows. Section 2 presents the study methods. The empirical results and their discussions are presented in Sections 3 and 4 respectively. Finally, Section 5 concludes and draws policy recommendations.

\section{Methodology}

\subsection{Analytical Framework}

This study employs multiple regression analysis to estimate the factors influencing farmers' perception of IBF in Kiambu County, Kenya. The dependent variables of the ordinary least squares (OLS) equations are the perception indices composed using a PCA, while the independent variables consist of farm/farmer and technology specific characteristics. Multiple regression is an extension of linear regression that analyses the correlation between more than one explanatory variable. According to [35], the OLS approach is used in estimating parameters in a linear model. This approach is well-suited to cases where the dependent variable is continuous and, in this case, the continuous nature of the perception indices qualifies the use of OLS. The OLS estimates have commendable statistical properties of being best linear unbiased estimators with minimum variance [35,36]. However, despite the distinction of the estimates, further model adequacy checks and validation are necessary following the linear regression to ascertain the appropriateness of the model [36].

Previous studies have applied factor scores as dependent variables in multiple linear regressions to understand farmers' perceptions. Most recently, reference [37] evaluated livestock farmers' perceptions of collaborative arrangements for manure exchange using multiple regressions based on factor analysis in Denmark. Reference [38] combined various farm and non-farm characteristics to compute factor scores that were used to elicit the determinants of coffee farmers' perceptions of risk. Other studies [39] compared dairy farmers risk perceptions with their risk management practices in Norway using a factor analysis. Whereas factor analysis reveals latent variables representing farmers' perceptions of IBF, the OLS permits in-depth exploration of the factors to consider when advising governments, farmers, research institutions and other stakeholders on IBF.

\subsubsection{The Principal Component Analysis Method}

The PCA method was applied in this study to generate factors with strong patterns explaining farmer's perceptions of IBF. PCA is a popular linear dimension reduction technique that reduces an excessive number of correlated variables by building a linear combination of uncorrelated variables that maximize the total variance explained. In doing so, relevant information is extracted from large data and the dimensionality of the data set is reduced by providing new and meaningful variables [40]. The use of PCA is validated through the Kaiser-Meyer-Olkin (KMO) measure of sampling adequacy where a value of at least 0.6 is preferred [41]. Components with eigen values of at least one are retained based on the Kaiser criterion [36]. Further, the component loadings are subjected to an orthogonal varimax rotation which produces uncorrelated factor scores for ease of interpretation. Reference [12] recommends the retention of statements with factor loadings above 0.5 for use in composing perception indices, a threshold adopted in this study.

Following [42], the index was generated using the weighted sum scores criterion [43] with slight modification relevant to the study context:

$$
P_{j}=\sum_{j=1}^{k} b_{k}\left(a_{j k}-a_{k}\right) / S_{k}
$$

where $P_{j}$ is the perception index for the $j$ th farmer, $b_{k}$ represents the weights /factor loading of the $k$ th perception statement; $a_{j k}$ is the response of the $j$ th farmer for the $k$ th perception statement, $a_{k}$ and $S_{k}$ are the mean and standard deviation of the $k$ th perception statement, 
respectively. The index varies from -1 to +1 and has a mean of zero and a standard deviation of zero.

\subsubsection{Estimation Strategy}

This study estimates five multiple regression equations. The dependent variables of the five equations are perception indices computed using the PCA method. The indices comprise of four individual IBF component indices derived from the factor scores of four key IBF perception components (performance, acceptability, versatility and marketability) and a composite index of the four individual IBF components. Following [36], the OLS is specified as a linear function of the parameters:

$$
Y_{n}=X_{k} \beta_{k}+\varepsilon
$$

where $Y_{n}$ is the $n$th factor score, $\beta_{k}$ denotes the vector of the parameters to be estimated; $X_{k}$ is the vector of the farm/farmer and technology specific characteristics such as: age, gender, years of formal education, income, wealth status, awareness of animal feeding on insects for nutritional purpose and group membership, while $\varepsilon$ captures the statistical random term that accounts for measurement error.

\subsection{Data Sources and Sampling Procedure}

The study used survey data from a sample of 310 households in Kiambu County selected using a three-stage sampling technique. In the first stage, three sub-counties namely: Kiambu Town, Ruiru and Thika Town were purposively selected from a total of 12 sub-counties in the County owing to their proximity to the City of Nairobi and engagement in diverse livestock enterprises; with a large number of chicken. In the second stage, a simple random sampling procedure was used to select two wards in each of the three selected sub-counties. The selected wards were: Riabai and Ndumberi (Kiambu Township); Mwihoko and Gatong'ora (Ruiru); and Gatuanyaga and Karimenu (Thika Town). Finally, a simple random sampling technique was applied to select 50 respondents in each ward from a sampling frame provided by the county livestock extension office. Following [44], an additional 15 respondents were interviewed to account for non-responses. A semistructured questionnaire that contained a mixture of open ended (where the respondent provides their own answer) and closed questions, which restrict the respondent to the choices provided was administered by trained enumerators to the respondents in face-toface interviews in March 2020. From the initially expected sample size of 315, the final sample size dropped slightly to 310 after data cleaning. Data were analyzed using SPSS 22 and STATA 14 softwares. Since IBF is not commercially available, the respondents were provided with background information on IBF products prior to the interviews. This background information pertaining to insect-based products included a pictorial description of the insect, its life-cycle and the harvesting stage, insect inclusion in feed formulation, the resulting compounded IBF products, consumers' readiness to purchase the resulting livestock products and the expected effect of the feed on livestock production.

\subsection{Definition and Measurement of Variables}

The questionnaire included a total of 18 perception statements and respondents were asked to rate their level of agreement on a five-point Likert scale of agreement/disagreement ranging from 1 (strongly disagree) to 5 (strongly agree). Slight modifications were made to transform the responses in the five-point scale to a four-point scale by eliminating the neutral responses to reduce ambiguity and to strengthen the validity of the factor scores. The 18 perception statements are presented in Section 3 Table 4. A PCA was used to reduce and group the statements into four broad IBF perception attributes (performance, acceptability, versatility and marketability) that have 7, 6, 3 and 2 retained factors respectively (see Section 3) (Table 5). The statements were based on a wide range of livestock performance indicators such as safety, growth, immunity, feed intake and socio-economic factors such as employment opportunities arising from the IBF value-chain, consumer acceptance of 
chicken reared on IBF, and environmental sustainability of the feed sources. Table 1 presents a description of the five perception indices. Each of the four individual perception indices had a mean of zero and a standard deviation of one whereas the composite index had a lower mean of approximately -0.15 and a higher standard deviation of about 7 (Table 1). The values of the scores and the overall index ranged between -3 to +3 and -17 to +17 , respectively (Table 1).

Table 1. Description of the farmers' perception indicators of insect-based feeds (IBF).

\begin{tabular}{|c|c|c|c|c|c|}
\hline Variable & Description & Mean & Standard Deviation & Min Value & Max Value \\
\hline Performance & $\begin{array}{l}\text { The nutrient composition and absence } \\
\text { of harmful substances that translate } \\
\text { into health of the livestock that farmers } \\
\text { can monitor. }\end{array}$ & 0.0 & 1.0 & -2.295 & 2.267 \\
\hline Acceptability & $\begin{array}{l}\text { Novel innovations that are guided by } \\
\text { the beliefs and social dynamics of } \\
\text { the community. }\end{array}$ & 0.0 & 1.0 & -1.896 & 2.361 \\
\hline Versatility & $\begin{array}{l}\text { Multi-purpose feed that considers the } \\
\text { differences in livestock breeds and their } \\
\text { feed requirements at different } \\
\text { growth stages. }\end{array}$ & 0.0 & 1.0 & -2.247 & 3.275 \\
\hline Marketability & $\begin{array}{l}\text { Cautious about how consumers of } \\
\text { livestock products may perceive } \\
\text { alterations to livestock diets. }\end{array}$ & 0.0 & 1.0 & -2.276 & 2.221 \\
\hline Perception index & $\begin{array}{l}\text { The overall index describing } \\
\text { perceptions about the feed as a whole }\end{array}$ & -0.147 & 6.921 & -16.426 & 16.495 \\
\hline
\end{tabular}

The farm/farmers characteristics that are later included in an OLS regression model as predictors for farmers' perception of IBF are presented in Table 2. Variables capturing a farmer's awareness of IBF attributes, off-farm sources, gender and membership to farmers' groups were measured as dummy variables. Age, wealth status (index) and education were measured as continuous variables. The wealth index was computed using the PCA method following [42]. Four items were used for the estimation of wealth index; animal housing structure [45]; ownership of a television set [46]; land size (above one acre) [47] and the total number of livestock units owned [48]. Since the index ranges from -1 to +1 , any household with a positive wealth index was classified as being wealthy.

Table 2. Description of the independent variables used in the regression model.

\begin{tabular}{ccc}
\hline Variable & Description & Measurement \\
\hline $\begin{array}{c}\text { Age } \\
\text { Gender }\end{array}$ & $\begin{array}{c}\text { Age of household head } \\
\text { Gender of household head }\end{array}$ & Male $=1 ;$ Female $=0$ \\
\hline Education & $\begin{array}{c}\text { Number of years of schooling } \\
\text { of household head }\end{array}$ & Years \\
\hline Off-farm income & $\begin{array}{c}\text { Whether a household had an } \\
\text { off-farm income source }\end{array}$ & Yes $=1 ;$ No $=0$ \\
\hline Awareness & Awareness of IBF attributes & Yes $=1 ;$ No $=0$ \\
\hline Wealth status & Wealth index of the household & Index (continuous) \\
\hline Group Membership & Membership to famers groups & Yes $=1 ;$ No $=0$ \\
\hline
\end{tabular}

\section{Results}

\subsection{Descriptive Results}

A summary of the socio-economic characteristics of the respondents is presented in Table 3. Over three-quarters of the households' heads were male and with an average 
age of 50 years. Household heads had an average of 12 years of formal education which corresponds to the attainment of a secondary school level of education. Eighty-one percent of the farmers had off-farm income sources that complemented their household income while $46 \%$ of the farmers were reportedly wealthy. Seventy-two percent of the respondents were members of farmer groups through which they procured inputs and marketed output. While $70 \%$ of the farmers were aware of the IBF attributes, nearly all respondents were willing to use commercial IBF once available in the market.

Table 3. Characteristics of chicken farmers in Kiambu County, Kenya.

\begin{tabular}{ccccc}
\hline Variable & Mean & Minimum & Maximum & Std \\
\hline Age & 50.29 & 24 & 88 & 12.10 \\
Education & 12.31 & 10 & 1.07 & 1.44 \\
Wealth Index & 0 & -0.93 & & 1.00 \\
Gender & 77.42 & & \\
Off-farm income & 81.29 & & & \\
Wealth status & 46.45 & & & \\
Group Membership & 72.26 & & & \\
Awareness & 69.03 & & & \\
\hline
\end{tabular}

\subsection{Rankings of Farmers' Perceptions of Insect-Based Feeds (IBF)}

The rankings of the farmers' level of agreement with the importance of various IBF attributes are presented in Table 4. The mean scores ranged between 1.89 and 3.50 with values closer to four indicating more favorable perceptions and values closer to one suggesting less favorable perceptions of IBF, based on a four-point Likert scale. The statement, "I am willing to use IBF once it is commercially available" had the highest mean score ranking of 3.5. The expectation that IBF will lead to employment creation was favorably perceived as indicated by the mean score of 3.43. The mean level of agreement with statements concerning religious and cultural appropriateness of IBF were also high (3.42 and 3.41 respectively), indicating favorable societal acceptance of IBF. Government approval and ability to differentiate the new feed from the conventional feed were also important considerations for farmers (mean scores of 3.29 and 3.27 respectively).

Table 4. Mean rankings of farmers' perceptions of IBF.

\begin{tabular}{|c|c|c|c|}
\hline Rank & Level of Agreement with IBF Perception Statements & Mean & SD \\
\hline 1 & I am willing to use IBF once it is commercially available & 3.50 & 0.611 \\
\hline 2 & IBF will create new employment opportunities i & 3.43 & 0.623 \\
\hline 3 & IBF is acceptable in my religion & 3.42 & 0.550 \\
\hline 4 & IBF is acceptable in my culture & 3.41 & 0.549 \\
\hline 5 & I will use IBF once the government approves its use & 3.29 & 0.672 \\
\hline 6 & $\begin{array}{c}\text { IBF should have distinguishing features for ease of } \\
\text { identification by farmers }\end{array}$ & 3.27 & 0.712 \\
\hline 7 & IBF is different from conventional feed & 3.10 & 0.786 \\
\hline 8 & IBF is safe for livestock use & 3.09 & 0.739 \\
\hline 9 & My customers will purchase livestock products reared on IBF & 3.08 & 0.737 \\
\hline 10 & IBF will lead to affordable feed & 3.01 & 0.763 \\
\hline 11 & IBF is more sustainable in terms of resource use & 3.00 & 0.774 \\
\hline 12 & IBF will lead to better price for livestock products & 2.84 & 0.749 \\
\hline 13 & IBF will lead to improved feed intake & 2.81 & 0.771 \\
\hline 14 & IBF will boost the immunity of the livestock & 2.66 & 0.757 \\
\hline 15 & Livestock fed with IBF will grow faster & 2.48 & 0.507 \\
\hline 16 & $\begin{array}{l}\text { Insects should be directly fed to livestock without mixing } \\
\text { with other ingredients }\end{array}$ & 2.03 & 0.779 \\
\hline 17 & IBF should be fed to all types of livestock & 1.99 & 0.820 \\
\hline 18 & IBF can also be fed to young livestock & 1.89 & 0.775 \\
\hline
\end{tabular}

Note: scale ranging from 1 (strongly disagree) to 4 (strongly agree) Source: Survey Data (2020). 
Farmers' perception of consumer acceptance of chicken products reared on IBF received a mean score of 3.08 suggesting that consumers would have favorable perceptions on livestock products derived from insect-based feeds. However, this finding is in contrast to earlier studies by $[43,49]$ who noted that farmers were uncertain about whether consumers would accept these products. One plausible explanation for this finding is that meat consumers in Kenya were ready to purchase meat products reared on IBF as noted by [50]. The belief that livestock will have improved feed intake and better tolerance towards diseases ranked moderately at 2.81 and 2.66 , respectively.

\subsection{Principal Components of Farmers Perceptions of IBF and Their Associated Loadings}

Results of the retained principal components and their respective loadings from each of the 18 perception statements are presented in Table 5 . The KMO test of sampling adequacy was 0.856 which is within the recommended threshold of 0.6 to 1 [41]. The Bartlett's test of sphericity was significant at a $1 \%$ level, implying that the items in each group had significant relationship. Further, the Cronbach's alpha, a measure of internal consistency, for each factor score was above 0.5 hence the perception statements were reliable for PCA. Based on the Kaiser criterion [41], the retained factors cumulatively explained about $64 \%$ of the variation. The performance component explained the maximum variation of about $35 \%$ with eight items showing factor loadings above the threshold of 0.5 for retention of statements. Farmers typically agreed with statements such as, "IBF will be more sustainable", "IBF is safe for livestock use" and "Livestock will have improved immunity".

Table 5. Loadings of IBF perception statements after varimax rotation.

\begin{tabular}{|c|c|c|c|c|}
\hline \multirow{2}{*}{ Perception Statements } & \multicolumn{4}{|c|}{ Rotated Components } \\
\hline & Performance & Acceptability & Versatility & Marketability \\
\hline IBF is more sustainable in terms of resource use & 0.785 & 0.193 & 0.136 & 0.096 \\
\hline IBF is different from conventional feed & 0.743 & 0.162 & 0.024 & 0.288 \\
\hline IBF will lead to affordable feed & 0.738 & 0.101 & 0.203 & 0.265 \\
\hline IBF is safe for animal use & 0.730 & 0.121 & -0.075 & 0.008 \\
\hline $\begin{array}{c}\text { IBF will create employment opportunities in the new } \\
\text { value chain }\end{array}$ & 0.618 & 0.304 & -0.135 & 0.126 \\
\hline IBF will boost the immunity of the animals & 0.598 & 0.086 & 0.251 & 0.532 \\
\hline IBF will lead to improved feed intake & 0.615 & -0.017 & 0.479 & 0.004 \\
\hline $\begin{array}{c}\text { IBF should have distinguishing features for ease of } \\
\text { identification by farmers }\end{array}$ & 0.551 & 0.387 & 0.130 & 0.131 \\
\hline I will use IBF once the government approves its use & 0.270 & 0.778 & 0.052 & -0.053 \\
\hline IBF is acceptable in my culture & 0.469 & 0.703 & -0.099 & 0.063 \\
\hline IBF is acceptable in my religion & 0.495 & 0.699 & -0.073 & 0.062 \\
\hline Animals fed with IBF with grow faster & 0.187 & -0.617 & -0.191 & -0.175 \\
\hline I am willing to use IBF once it is commercially available & 0.486 & 0.510 & -0.273 & 0.224 \\
\hline IBF can also be fed to young ones of animals & 0.107 & 0.065 & 0.823 & 0.104 \\
\hline IBF should be fed to all types of animals & -0.069 & 0.159 & 0.781 & 0.120 \\
\hline $\begin{array}{l}\text { Insects should be directly fed to animals without mixing } \\
\text { with other ingredients }\end{array}$ & 0.099 & -0.0180 & 0.458 & -0.215 \\
\hline IBF will lead to better price for the animal products & 0.259 & 0.066 & 0.104 & 0.838 \\
\hline $\begin{array}{l}\text { My customers will purchase meat and egg products reared } \\
\text { on IBF }\end{array}$ & 0.140 & 0.150 & -0.102 & 0.809 \\
\hline Eigen values & 6.276 & 2.131 & 1.530 & 1.337 \\
\hline Variance explained (\%) & 34.88 & 11.83 & 8.50 & 7.42 \\
\hline Cumulative variance explained (\%) & 34.88 & 46.71 & 55.21 & 62.63 \\
\hline Cronbach's alpha & 0.877 & 0.670 & 0.703 & 0.749 \\
\hline
\end{tabular}

Notes: Cronbach's alpha $=0.868$; Kaiser-Meyer-Olkin $(\mathrm{KMO})$ measure of sampling adequacy $=0.856$; Bartlett's test of sphericity: Chi-square $(\mathrm{df})=2671.71$ (153). Source: Survey Data (2020).

The component of acceptability explained $11.84 \%$ of the cumulative variation and recorded five statements with factor loadings above the 0.5 threshold. It was common for farmers to indicate that "I will use IBF when the government approves it", "IBF 
is acceptable in my religion", "IBF is acceptable in my culture" and "IBF will create employment opportunities". Two statements namely; "IBF should be fed to all types of livestock" and "IBF should be fed to young livestock" satisfied the 0.5 factor loading threshold and had the highest contribution to the component on versatility which explained about $9 \%$ of the variation. This is understandable because farmers keep different breeds of animals on the same farm. Marketability recorded two statements with factor loadings above 0.5 and explained the least variation of approximately $7 \%$ in the analysis.

\subsection{Econometric Results}

The results of the multiple linear regression analysis are presented in Table 6. The factors influencing the individual IBF perception components are in agreement with those of the composite index. However, the coefficients of the latter model are larger than those of the former models, possibly because of the effect of aggregation. The adjusted R-squared values, which measure goodness of fit, were low ( $2 \%$ to $26 \%$ ) but within the range of similar studies. For instance, references $[37,38,51]$ have reported values of as low $1 \%$ for linear regression models of survey data. According to [35], it is not unusual to observe low goodness-of-fit in regression analysis using cross-sectional data and in behavioral studies. All the models except that of versatility were significant at 1\%. The model diagnostic tests were performed to ascertain the absence of correlations among the factor scores and to further justify the use of individual linear regressions (Appendix A).

Overall, awareness, off-farm income, wealth status and group membership positively and significantly influenced farmers' perceptions of commercial IBF at least at the 5\% level. Farmers who were aware of the IBF attributes were more likely to have favourable perceptions of IBF than their counterparts who were not aware. This finding held true for all the perception indices except that of the versatility factors. Similarly, farmers who had an off-farm income source were more likely to have more favourable perceptions on commercial IBF than farmers who did not have an off-farm income source. This was found to hold for the composite index, the performance index and the acceptability index. More wealthy farmers had higher likelihoods of having more favourable perceptions on commercial IBF that their less wealthy counterparts. This was the case for the composite, performance and versatility indices. Finally, households that were members of farmer groups were more likely to have to have more favourable perceptions on IBF than those households who were not members of farmers groups. This later finding holds for the composite, performance and acceptability indices.

Table 6. Multiple regression estimates of the factors influencing farmers' perceptions of IBF.

\begin{tabular}{cccccc}
\hline \multirow{2}{*}{ Explanatory Variables } & \multicolumn{3}{c}{ Regression Parameter Estimates } \\
\cline { 2 - 6 } & Composite Index & Performance & Acceptability & Versatility & Marketability \\
\hline Age & $-0.031(0.029)$ & $-0.001(0.563)$ & $-0.008(0.005)$ & $0.005(0.005)$ & $-0.003(0.005)$ \\
Gender & $-0.064(0.839)$ & $-0.094(0.131)$ & $0.098(0.135)$ & $-0.028(0.0140)$ & $0.047(0.137)$ \\
Education & $0.261(0.246)$ & $-0.008(0.038)$ & $-0.056(0.040)$ & $0.107(0.041)^{* * *}$ & $0.112(0.040)^{* * *}$ \\
Awareness & $3.987(0.748)^{* * *}$ & $0.338(0.116)^{* * *}$ & $0.428(0.120)^{* * *}$ & $-0.101(0.125)$ & $0.383(0.122)^{* * *}$ \\
Off-farm income & $4.718(0.912)^{* * *}$ & $0.562(0.142)^{* * *}$ & $0.415(0.147)^{* * *}$ & $-0.082(0.152)$ & $0.237(0.149)$ \\
Wealth index & $1.311(0.345)^{* * *}$ & $0.212(0.054)^{* * *}$ & $-0.018(0.055)$ & $0.136(0.058)^{* *}$ & $0.027(0.056)$ \\
Group membership & $2.548(0.774)^{* * *}$ & $0.318(0.120)^{* * *}$ & $0.270(0.124)^{* * *}$ & $0.019(0.129)$ & $-0.035(0.126)$ \\
Constant & $-10.187(3.616)$ & $-0.724(0.563)$ & $0.194(0.581)$ & $-1.404(0.604)$ & $-1.699(0.589)$ \\
Adjusted R-squared & 0.2676 & 0.1505 & 0.0930 & 0.0221 & 0.0675 \\
Observations $(n)$ & 310 & & & & \\
\hline
\end{tabular}

Notes: ${ }^{* * *}$ and ${ }^{* *}$ denote statistical significance of variables and models at $1 \%$ and $5 \%$ levels, respectively. Standard errors are presented in parentheses. Source: Survey Data (2020).

\section{Discussion}

In conformity with our expectations, we found that a majority of the chicken farmers in this study had positive perceptions of IBF. Almost all respondents in this study were 
willing to use commercial IBF once available in the market. The statement, "I am willing to use IBF once it is commercially available" had a mean score ranking of 3.5 out of a possible 5 further reinforcing farmers' acceptability of IBF. Moreover, farmers expected that the introduction of IBF will lead to employment creation as indicated by the mean score of 3.43. Studies by $[19,43]$ observed that farmers and other stakeholders are willing to rear insects, for income diversification and other economic benefits.

The PCA method was used to compute four perception indices; performance, acceptability, versatility and marketability from retained factors out of the 18 perception statements. The retained factors cumulatively explained about $64 \%$ of the variation and the four indices were used as dependent variables in the regression analysis. We found awareness, off-farm income, wealth status and group membership to positively and significantly influence farmer's perceptions of commercial IBF at least at the 5\% level (Table 6). These findings suggest that commercial IBF was perceived to be more important than conventional chicken feed by farmers who were aware of the IBF attributes, who had an off-farm income source, were wealthy and those who were members of farmers groups.

The performance aspects of IBF such as improved feed intake and improved immunity of livestock reared on IBF were perceived to be more important to the farmers who were aware of IBF attributes. This implies that awareness creation and dissemination is important in promoting use of IBF among chicken farmers in Kenya. Our findings are supported by $[30,49]$ who reported that prior exposure to a particular insect positively contributed to farmers' willingness to use IBF. Similarly, the performance aspects of IBF were perceived to be more important by farmers who belonged to groups than those who were not members of any group. Groups play a crucial role in the transfer of information particularly among smallholder farmers who are often members of more than one group [52]. Wealthier farmers and those with access to off-farm income sources perceived the performance aspects of IBF to be more important than their less wealthy counterparts and those with no access to off-farm income respectively.

The acceptability elements of IBF were more important to farmers with prior awareness of the nutritional benefits of feeding chicken on insects and those belonging to farmer groups than their counterparts who were not aware. Farmers with off-farm income sources were more keen on the acceptability elements of IBF than those without an off-farm income source possibly because the supplementary income would allow them to purchase IBF once it is commercially available. This is in line with the finding by [53] that farmers with offfarm sources had more positive attitudes towards new technologies. The versatility features of IBF were more important for wealthy farmers than their less endowed counterparts. Similarly, the more educated farmers perceived the versatility features of IBF to be more important than their less-educated counterparts. High literacy levels facilitate the search, access and comprehension of new and existing information. Educated farmers perceive market research as a critical component to safeguard against economic losses experienced during distress sales [54].

Finally, the marketability aspects of IBF were perceived to be more important by the more educated farmers and those that were aware of the fact that livestock feed on insects for nutritional benefits than their less-educated counterparts and those who are not aware of this. This might be attributed to their high level of literacy and resource endowments which allow them to access and synthesize market information and to purchase high valued livestock breeds. Characteristics such as consumer acceptance of meat and eggs from chicken reared on IBF and the ability of these products to fetch higher prices in the market were rated highly by more educated farmers than their less educated counterparts.

\section{Conclusions and Policy Recommendations}

This paper evaluates farmer's perceptions of commercial IBF in Kiambu County, Kenya. It employs a PCA to construct perception indices that are used in multiple linear regressions on a sample of farmers selected using a multistage sampling procedure. A sample of 310 farmers was used. We find chicken farmers in Kiambu County, Kenya, to 
have positive perceptions on commercial IBF. Our findings revealed favourable patterns of farmers' perceptions of commercial IBF in Kenya with regard to feed performance, social acceptability of the IBF feed, versatility of the feed and marketability of meat and egg from chicken raised on the novel insect-based feeds. Farmers' awareness of IBF attributes, membership to groups, education, off-farm income sources and their wealth status were the most important drivers of their perceptions on IBF. However, it should be noted that these findings are context-specific and might not be applicable in countries with different cultural backgrounds. Future studies should explore coverage of more counties to improve the applicability of the results.

Given that perceptions are based on exposure to knowledge, the study recommends that policy interventions by county governments in Kenya should be geared towards increasing farmers' technical knowledge and ability to evaluate the performance of different animal breeds reared on IBF through technical trainings at group level to capitalize on peer learning. Interventions such as experimental demonstrations that increase farmers' technical knowledge on the productivity of livestock fed on IBF are crucial in reducing farmers' uncertainties towards acceptability of IBF. Public-private partnerships with resource-endowed farmers and farmer groups are recommended to improve knowledge sharing on IBF. Moreover, since such policy measure might set the backdrop for adoption of insect-based animal feeds, our findings would help shape the institutional, legal, regulatory, financial and economic aspects that affect farmers and commercial influencers.

Author Contributions: A.O.O.: Conceptualization, data curation, formal analysis, investigation, methodology, visualization, writing-original draft; J.M.N.: Conceptualization, formal analysis, supervision, investigation, methodology, visualization, review and editing; D.J.O.: Conceptualization, investigation, methodology, visualization, supervision, review and editing; M.K.: Conceptualization, methodology, visualization, supervision, review and editing; C.M.T.: Visualization, review and editing, project administration, funding acquisition. All authors have read and agreed to the published version of the manuscript.

Funding: Financial support for this research was provided by the Canadian International Development Research Centre (IDRC) and the Australian Centre for International Agricultural Research (ACIAR) (INSFEED-Phase 2: Cultivate Grant No: 108866-001), Norwegian Agency for Development Cooperation, the Section for research, innovation, and higher education grant number RAF-3058 KEN-18/0005 (CAP-Africa), Netherlands Organization for Scientific Research, WOTRO Science for Global Development (NWO-WOTRO) (ILIPA-W 08.250.202) and the Rockefeller Foundation (SiPFeed-Grant No: 2018 FOD 009). We also gratefully acknowledge the support of International Centre of Insect Physiology and Ecology (icipe) core funding provided by United Kingdom's Foreign, Commonwealth and Development Office (FCDO); the Swedish International Development Cooperation Agency (Sida); the Swiss Agency for Development and Cooperation (SDC); the Federal Democratic Republic of Ethiopia; and the Government of the Republic of Kenya. The first author (A.O.O) was also financially supported by the African Economic Research Consortium (AERC).

Institutional Review Board Statement: Not applicable.

Informed Consent Statement: Not applicable.

Data Availability Statement: Data used in this study can be availed by the authors upon reasonable request.

Acknowledgments: The authors gratefully acknowledge contributions from Henry Mwololo for his revisions on the earlier draft, and the livestock extension officers of Kiambu County as well as the farmers for their willingness to assist in the provision of data for this research.

Conflicts of Interest: The authors declare no conflict of interest. The funders had no role in study design, data collection and analysis, decision to publish, or preparation of the manuscript. Therefore, the views expressed herein do not necessarily reflect the official opinion of the donors. 


\section{Appendix A}

Table A1. Model diagnostics of the MANOVA for multivariate multiple linear regression.

\begin{tabular}{ccc}
\hline Model Diagnostic & Statistic & F-Value \\
\hline Wilks' lambda & $0.621^{* * *}$ & 5.44 \\
Pillai's trace & $0.416^{* * *}$ & 5.01 \\
Lawley-Hotelling trace & $0.551^{* * *}$ & 5.86 \\
Roy's largest root & $0.426^{* * *}$ & 18.40 \\
Observations $(n)$ & 310 & \\
Residual & 302 & \\
\hline
\end{tabular}

Notes: ${ }^{* * *}$ denotes statistical significance at the $1 \%$ level. Source: Survey Data (2020).

\section{References}

1. Food and Agriculture Organization of the United Nations (FAO). Contribution of agricultural growth to reduction of poverty, hunger and malnutrition. In The State of Food Insecurity in the World; FAO: Rome, Italy, 2012.

2. Kabubo-Mariara, J. Global warming and livestock husbandry in Kenya: Impacts and adaptations. Ecol. Econ. 2009, 68, 1915-1924. [CrossRef]

3. Republic of Kenya. National Livestock Policy; Ministry of Agriculture, Livestock, Fisheries and Irrigation, State Department for Livestock, Government Printer: Nairobi, Kenya, 2019.

4. Republic of Kenya. The National Livestock Policy; Ministry of Livestock Development, Government Printer: Nairobi, Kenya, 2008.

5. Ssepuuya, G.; Namulawa, V.; Mbabazi, D.; Mugerwa, S.; Fuuna, P.; Nampijja, Z.; Ekesi, S.; Fiaboe, K.; Nakimbugwe, D. Use of insects for fish and poultry compound feed in sub-Saharan Africa-A systematic review. J. Insects Food Feed. 2017, 3, $289-302$. [CrossRef]

6. Omondi, S.O. Urban-Based Agriculture and Poultry Production: The Case of Kisumu and Thika in Kenya. Ph.D. Thesis, Lund University, Lund, Sweden, 2018.

7. Kasule, L.; Katongole, C.; Nambi-Kasozi, J.; Lumu, R.; Bareeba, F.; Presto, M.; Ivarsson, E.; Lindberg, J.E. Low nutritive quality of own-mixed chicken rations in Kampala City, Uganda. Agron. Sustain. Dev. 2014, 34, 921-926. [CrossRef]

8. Van Huis, A. Insects as food and feed, a new emerging agricultural sector: A review. J. Insects Food Feed. 2020, 6, 27-44. [CrossRef]

9. Dobermann, D.; Swift, J.A.; Field, L.M. Opportunities and hurdles of edible insects for food and feed. Nutr. Bull. 2017, 42, 293-308. [CrossRef]

10. Makkar, H.P.; Tran, G.; Heuzé, V.; Ankers, P. State-of-the-art on use of insects as animal feed. Anim. Feed. Sci. Technol. 2014, 197, 1-33. [CrossRef]

11. Aarts, K. How to develop insect-based ingredients for feed and food? A company's perspective. J. Insects Food Feed. 2020, 6, 67-68. [CrossRef]

12. Domingues, C.H.D.F.; Borges, J.A.R.; Ruviaro, C.F.; Gomes Freire Guidolin, D.; Rosa Mauad Carrijo, J. Understanding the factors influencing consumer willingness to accept the use of insects to feed poultry, cattle, pigs and fish in Brazil. PLOS ONE 2020, 15, e0224059. [CrossRef]

13. Bbosa, T.; Ndagire, C.T.; Mukisa, I.M.; Fiaboe, K.K.M.; Nakimbugwe, D. Nutritional Characteristics of Selected Insects in Uganda for Use as Alternative Protein Sources in Food and Feed. J. Insect Sci. 2019, 19, 1-8. [CrossRef]

14. Schiavone, A.; Cullere, M.; De Marco, M.; Meneguz, M.; Biasato, I.; Bergagna, S.; Dezzutto, D.; Gai, F.; Dabbou, S.; Gasco, L.; et al. Partial or total replacement of soybean oil by black soldier fly larvae (Hermetia illucens L.) fat in broiler diets: Effect on growth performances, feed-choice, blood traits, carcass characteristics and meat quality. Ital. J. Anim. Sci. 2017, 16, 93-100. [CrossRef]

15. Altmann, B.A.; Neumann, C.; Rothstein, S.; Liebert, F.; Mörlein, D. Do dietary soy alternatives lead to pork quality improvements or drawbacks? A look into micro-alga and insect protein in swine diets. Meat Sci. 2019, 153, 26-34. [CrossRef] [PubMed]

16. Biasato, I.; Renna, M.; Gai, F.; Dabbou, S.; Meneguz, M.; Perona, G.; Martinez, S.; Lajusticia, A.C.B.; Bergagna, S.; Sardi, L.; et al. Partially defatted black soldier fly larva meal inclusion in piglet diets: Effects on the growth performance, nutrient digestibility, blood profile, gut morphology and histological features. J. Anim. Sci. Biotechnol. 2019, 10, 1-11. [CrossRef] [PubMed]

17. Boloh, Y. Insect proteins inch toward approval for EU animal feed: After the authorization for insect proteins in aquafeed in July 2017, Europe may accept insect proteins for poultry and pig feeds in 2019. Feed Strategy 2018, 69, 16.

18. Veldkamp, T.; Bosch, G. Insects: A protein-rich feed ingredient in pig and poultry diets. Anim. Front. 2015, 5, 45-50.

19. Chia, S.Y.; Tanga, C.M.; van Loon, J.J.; Dicke, M. Insects for sustainable animal feed: Inclusive business models involving smallholder farmers. Curr. Opin. Environ. Sustain. 2019, 41, 23-30. [CrossRef]

20. Nyakeri, E.; Ogola, H.; Ayieko, M.; Amimo, F. An open system for farming black soldier fly larvae as a source of proteins for smallscale poultry and fish production. J. Insects Food Feed. 2017, 3, 51-56. [CrossRef]

21. Jha, S.; Kaechele, H.; Lana, M.; Amjath-Babu, T.; Sieber, S. Exploring Farmers' Perceptions of Agricultural Technologies: A Case Study from Tanzania. Sustainability 2020, 12, 998. [CrossRef] 
22. Oo, S.P.; Usami, K. Farmers' Perception of Good Agricultural Practices in Rice Production in Myanmar: A Case Study of Myaungmya District, Ayeyarwady Region. Agriculture 2020, 10, 249. [CrossRef]

23. Llagostera, P.F.; Kallas, Z.; Reig, L.; de Gea, D.A. The use of insect meal as a sustainable feeding alternative in aquaculture: Current situation, Spanish consumers' perceptions and willingness to pay. J. Clean. Prod. 2019, 229, 10-21. [CrossRef]

24. Fatch, P.F.; Masangano, C.; Kamoto, J.; Jordan, I.; Hilger, T.; Mambo, I.; Nuppenau, E.A. Are farmer perceptions among significant determinants of adoption of agricultural diversity in Malawi? A case of Lilongwe district. J. Agric. Rural Dev. Trop. Subtrop. 2020, 121, 277-288. [CrossRef]

25. Sogari, G.; Amato, M.; Biasato, I.; Chiesa, S.; Gasco, L. The Potential Role of Insects as Feed: A Multi-Perspective Review. Animals 2019, 9, 119. [CrossRef] [PubMed]

26. Kinyuru, J.; Ndung'U, N. Promoting edible insects in Kenya: Historical, present and future perspectives towards establishment of a sustainable value chain. J. Insects Food Feed. 2020, 6, 51-58. [CrossRef]

27. Waithanji, E.; Affognon, D.H.; King'Ori, S.; Diiro, G.; Nakimbugwe, D.; Fiaboe, K.K. Insects as feed: Gendered knowledge attitudes and practices among poultry and Pond Fish farmers in Kenya. NJAS Wagening. J. Life Sci. 2020, 92, 100312. [CrossRef]

28. Otieno, D.J.; Ogutu, S.O. Consumer willingness to pay for chicken welfare attributes in Kenya. J. Int. Food Agribus. Mark. 2019, 32, 379-402. [CrossRef]

29. Wambugu, R.N. Analysis of Welfare Indicators for Chickens in Large-Scale Contract and Non-Contract Broiler Farms in Kenya. MSc. Ph.D. Thesis, University of Nairobi, Nairobi, Kenya, 2019.

30. Chia, S.Y.; Macharia, J.; Diiro, G.M.; Kassie, M.; Ekesi, S.; Van Loon, J.J.A.; Dicke, M.; Tanga, C.M. Smallholder farmers' knowledge and willingness to pay for insect-based feeds in Kenya. PLoS ONE 2020, 15, e0230552. [CrossRef] [PubMed]

31. Republic of Kenya. County Integrated Development Plan (CIDP)—County Government of Kiambu: 2018-2022; Government Printer: Nairobi, Kenya, 2018.

32. McCarron, M.; Munyua, P.; Cheng, P.-Y.; Manga, T.; Wanjohi, C.; Moen, A.; Mounts, A.; Katz, M.A. Understanding the poultry trade network in Kenya: Implications for regional disease prevention and control. Prev. Veter Med. 2015, 120, 321-327. [CrossRef]

33. Otieno, D.J.; Kerubo, D.M. Characterization of consumers' purchase and consumption behaviour for chicken in Nairobi, Kenya: Targeted insights for value chain positioning. In Proceedings of the 5th International Conference of the African Association of Agricultural Economists, Addis Ababa, Ethiopia, 23-26 September 2016. [CrossRef]

34. Kenya National Bureau of Statistics (KNBS). Basic Report on Well-Being in Kenya: Based on the Integrated Household Budget Survey; Government Printer: Nairobi, Kenya, 2018.

35. Greene, W.H. Econometric Analysis, 7th ed.; New York University: New York, NY, USA, 2012.

36. Montgomery, D.C.; Peck, E.A.; Vining, G.G. Introduction to Linear Regression Analysis, 5th ed.; John Wiley \& Sons: Hoboken, NJ, USA, 2012.

37. Asai, M.; Langer, V.; Frederiksen, P.; Jacobsen, B.H. Livestock farmer perceptions of successful collaborative arrangements for manure exchange: A study in Denmark. Agric. Syst. 2014, 128, 55-65. [CrossRef]

38. Abebaw, D.; Holm-Müller, K.; Mburu, J. Understanding the perceived importance of risk for coffee growers: Empirical evidence from Ethiopia. J. Int. Agric. 2006, 45, 253-267.

39. Flaten, O.; Lien, G.; Koesling, M.; Valle, P.; Ebbesvik, M. Comparing risk perceptions and risk management in organic and conventional dairy farming: Empirical results from Norway. Livest. Prod. Sci. 2005, 95, 11-25. [CrossRef]

40. Hair, J.F.; Black, W.C.; Babin, B.J.; Anderson, R.E. Multivariate Data Analysis, International version; Pearson: Hoboken, NJ, USA, 2010.

41. Kaiser, H.F. An index of factorial simplicity. Psychometrika 1974, 39, 31-36. [CrossRef]

42. Mwololo, H.; Nzuma, J.; Ritho, C. Do farmers' socio-economic characteristics influence their preference for agricultural extension methods? Dev. Pract. 2019, 29, 844-853. [CrossRef]

43. DiStefano, C.; Zhu, M.; Mindrila, D. Understanding and using factor scores: Considerations for the applied researcher. Pract. Assess. Res. Eval. 2009, 14, 20.

44. Harapan, H.; Rajamoorthy, Y.; Anwar, S.; Bustamam, A.; Radiansyah, A.; Angraini, P.; Fasli, R.; Salwiyadi, S.; Bastian, R.A.; Oktiviyari, A.; et al. Knowledge, attitude, and practice regarding dengue virus infection among inhabitants of Aceh, Indonesia: A cross-sectional study. BMC Infect. Dis. 2018, 18, 1-16. [CrossRef] [PubMed]

45. Carrique-Mas, J.; Van, N.T.B.; Van Cuong, N.; Truong, B.D.; Kiet, B.T.; Thanh, P.T.H.; Lon, N.N.; Giao, V.T.Q.; Hien, V.B.; Padungtod, P.; et al. Mortality, disease and associated antimicrobial use in commercial small-scale chicken flocks in the Mekong Delta of Vietnam. Prev. Vet. Med. 2019, 165, 15-22. [CrossRef]

46. Wossen, T.; Abdoulaye, T.; Alene, A.; Haile, M.G.; Feleke, S.; Olanrewaju, A.; Manyong, V. Impacts of extension access and cooperative membership on technology adoption and household welfare. J. Rural. Stud. 2017, 54, 223-233. [CrossRef] [PubMed]

47. Alwang, J.; Gotor, E.; Thiele, G.; Hareau, G.; Jaleta, M.; Chamberlin, J. Pathways from research on improved staple crop germplasm to poverty reduction for smallholder farmers. Agric. Syst. 2019, 172, 16-27. [CrossRef]

48. Ogada, M.J.; Rao, E.J.; Radeny, M.; Recha, J.W.; Solomon, D. Climate-smart agriculture, household income and asset accumulation among smallholder farmers in the Nyando basin of Kenya. World Dev. Perspect. 2020, 18, 100203. [CrossRef]

49. Ipara, B.O.; Otieno, D.J.; Nyikal, R.; Makokha, N.S. The contribution of extensive chicken production systems and practices to Newcastle disease outbreaks in Kenya. Trop. Anim. Health Prod. 2021, 53, 1-13. [CrossRef] 
50. Etuah, S.; Ohene-Yankyera, K.; Liu, Z.; Mensah, J.O.; Lan, J. Determinants of cost inefficiency in poultry production: Evidence from small-scale broiler farms in the Ashanti Region of Ghana. Trop. Anim. Health Prod. 2019, 52, 1149-1159. [CrossRef]

51. Ebbesvik, M.; Lien, G.; Flaten, O.; Valle, P.S.; Arntzen, H. Risk and risk management in organic and conventional cash crop farming in Norway. Food Econ. Acta Agric. Scand. Sect. C 2004, 1, 195-206. [CrossRef]

52. Onsongo, V.; Osuga, I.M.; Gachuiri, C.K.; Wachira, A.M.; Miano, D.M.; Tanga, C.M.; Ekesi, S.; Nakimbugwe, D.; Fiaboe, K.K.M. Insects for Income Generation Through Animal Feed: Effect of Dietary Replacement of Soybean and Fish Meal With Black Soldier Fly Meal on Broiler Growth and Economic Performance. J. Econ. Ėntomol. 2018, 111, 1966-1973. [CrossRef] [PubMed]

53. Verbeke, W.; Spranghers, T.; De Clercq, P.; De Smet, S.; Sas, B.; Eeckhout, M. Insects in animal feed: Acceptance and its determinants among farmers, agriculture sector stakeholders and citizens. Anim. Feed. Sci. Technol. 2015, 204, 72-87. [CrossRef]

54. Sebatta, C.; Ssepuuya, G.; Sikahwa, E.; Mugisha, J.; Diiro, G.; Sengendo, M.; Fuuna, P.; Fiaboe, K.; Nakimbugwe, D. Farmers' acceptance of insects as an alternative protein source in poultry feeds. Int. J. Agric. Res. Innov. Technol. 2018, 8, 32-41. [CrossRef] 